\title{
WAGONS IN SARMATIAN BURIALS OF THE LOWER VOLGA AND LOWER DON KURGANS
}

Part $1^{1}$

\author{
Boris A. Raev \\ Federal Research Centre The Southern Scientific Centre of the Russian Academy of Sciences, \\ Rostov-on-Don, Russian Federation
}

\begin{abstract}
The article deals with two burial sites from the Sarmatian kurgans located in the Lower Volga region. Three wheels and two axles of the wagon covering the grave in a wooden frame were discovered in the burial close to the Merkel village excavated in 1929 in the upper reaches of the Karamysh River, on the territory of the Volga German Autonomous Soviet Socialist Republic. Some details have shown that few parts of the wagon were placed in the grave in unfinished form. The diary records of the escavations author Paul Rau, which were found in archives, contained important information. The second burial was explored in the early 1970s in the Astrakhan region. Two wheels were preserved in the grave closing the access to the inner chamber. An analysis of the construction of the graves and wagons parts enables to speak about two types of grave structures in which wagons were placed - simple graves, and graves with inner chambers. The simple graves are contained not only of wheels but also of body parts and other parts of wagon as well. While graves with inner chambers includes only wheels, closing the inner chamber. Parts of old wagons, their unfinished parts, optionally defective ones, have been used in the burial ceremony. The search for analogs refers to the burials of Central Asia and Altai region, which possesses the evidences of two-axle wagons genesis. The one-axle wagons which appeared in the Eastern European steppes at later time are connected originally to the same region. The second part of this article will focus on the origin of the burial rite itself, as well as the spreading time of the tradition, its ways, and mechanism - from the eastern to the western regions of the Eurasian steppes.

Key words: Lower Volga region, excavations of Paul Rau, Volga expedition of the Academy of Sciences of the USSR and Moscow State University, Sarmatian wagons, Central Asian traditions.

Citation. Raev B.A., 2020. Povozki v sarmatskih pogrebeniyah nizhnevolzhskih i nizhnedonskih kurganov. Chast' 1 [Wagons in Sarmatian Burials of the Lower Volga and Lower Don Kurgans. Part 1]. Nizhnevolzhskiy Arkheologicheskiy Vestnik [The Lower Volga Archaeological Bulletin], vol. 19, no. 2, pp. 183-199. DOI: https://doi.org/10.15688/nav.jvolsu.2020.2.10
\end{abstract}

УДК 930.26(470+571):636.083.7

Дата поступления статьи: 12.07.2020

ББК $63.48(2)-413$

Дата принятия статьи: 24.11.2020

\section{ПОВОЗКИ В САРМАТСКИХ ПОГРЕБЕНИЯХ НИЖНЕВОЛЖСКИХ И НИЖНЕДОНСКИХ КУРГАНОВ \\ Yасть $1^{1}$}

\section{Борис Аронович Раев} \\ Федеральный исследовательский центр Южный научный центр Российской академии наук, \\ г. Ростов-на-Дону, Российская Федерация
}

Аннотация. В статье рассматриваются два погребения из сарматских курганов на Нижней Волге. В погребении у с. Меркель, раскопанном в 1929 г. в верховьях р. Карамыш на территории АССР немцев Поволжья, были обнаружены три колеса и две оси повозки, перекрывающие захоронение в деревянной раме. Некото- 
рые детали свидетельствуют о том, что части повозки были помещены в могилу в незавершенном виде. Важную информацию содержали дневниковые записи автора раскопок Пауля Рау, обнаруженные в архиве. Второе погребение исследовалось в начале 1970-х гг. в Астраханской области. Здесь в закладе подбойного захоронения сохранились два колеса. Анализ конструкции могильных ям и деталей повозок позволяет говорить о двух типах могильных сооружений, в которые помещались повозки, - простых ямах и ямах с подбоями. В первые иногда укладывали не только колеса, но и отдельные части кузова и иные части повозки. В погребениях подбойных для перекрытия устья подбоя использовали только колеса. Для погребальной церемонии применяли части старых повозок или их не доделанные до конца, может быть бракованные, части. Поиски аналогий заставляют обратиться к захоронениям Центральной Азии и Алтая, где есть свидетельства генезиса двуосных повозок. Одноосные повозки, появляющиеся в Восточноевропейских степях в более позднее время, связаны своим происхождением с этим же регионом. Происхождению, а также времени, путям и механизму распространения традиции из восточных в западные регионы степей Евразии будет посвящена вторая часть представленной здесь работы.

Ключевые слова: Нижнее Поволжье, раскопки Пауля Рау, Поволжская экспедиция ИА АН СССР и МГУ, повозки сарматского времени, центральноазиатские традиции.

Цитирование. Раев Б. А., 2020. Повозки в сарматских погребениях нижневолжских и нижнедонских курганов. Часть 1 // Нижневолжский археологический вестник. Т. 19, № 2. С. 183-199. DOI: https://doi.org/ 10.15688/nav.jvolsu.2020.2.10

Три года назад В.М. Клепиков опубликовал статью, посвященную использованию повозок и их частей в закладе могильных ям раннесарматских погребений в Нижнем Поволжье [Клепиков, 2017]. Целью моей работы является уточнение характеристики некоторых деталей повозок по архивным материалам, исправление неточностей, допущенных авторами некоторых публикаций, и сравнение нижневолжских повозок и повозок из сарматских курганов Нижнего Подонья. Отдельной темой во второй части работы будет связь повозок из курганов Юго-Восточной Европы с повозками пазырыкского времени и колесницами эпохи Хань.

Прежде всего, следует исправить несправедливость, допущенную по отношению к Паулю Рау - одному из самых грамотных и успешных археологов 20-х гг. ХХ в., тонкие и точные полевые наблюдения которого до настоящего времени не утратили своего источниковедческого значения. Именно им, а не Иваном Васильевичем Синицыным [ср.: Клепиков, 2017, с. 21] летом 1929 г. были исследованы несколько курганов у с. Меркель на территории Автономной Республики немцев Поволжья ${ }^{2}$, в том числе курган G2, в третьем погребении которого были найдены части деревянной повозки: две разрубленные оси и три колеса со спицами. Через 18 лет подготовленный П. Рау отчет [Рау, 1929] в полном объеме со всеми беловыми чертежами и описаниями был перепечатан И.В. Синицыным [Синицын,
1947]. Поскольку провинциальная публикация 1947 г. стала раритетом, считаю важным опубликовать эту часть отчета Пауля Рау, тем более что она невелика по объему [Рау, 1929, c. $21-23]^{3}$.

Могила 3-я, впускная.

Западная половина кургана.

Северный конец траншеи D.

Удлиненная с закругленными углами могильная яма, врезанная в

$21 / 22$

материк до глинистой подпочвы. Длина 2,40, ширина в головах (южный конец) 1,04, в ногах - 0,85. Расположение по длине с С на Ю с уклонением к CВ-Ю3. Могильная яма уже отметилась в верхних слоях насыпи сырым и рыхлым составом заполнявшей ее почвы. Уже с поверхности попадались разрозненные березовые сучья, лежавшие ближе к горизонту сплошным слоем, будучи вдавлены в промежутки между колесами и осями, заслонявшими гроб. Осей было 4, а колес 3 . Оси дубовые. Из дуба сделаны также спицы в колесах, ступицы же и ободы - из мягкой породы и плохой сохранности. От ободов сохранились лишь незначительные следы. Оси, повидимому, не были еще в употреблении, так как стержни их сохранились четырехгранными. Все 4 экземпляра до положения их в могилу были приведены в негодность: у каждой отрублен один из стержней. Располагались они в могиле следующим образом: одна прислонена к западной стенке могилы, уцелевшим стержнем вверх; две упирались поврежденным концом в дно у западной стенки, а в стержни их были вставлены колеса ${ }^{4}$, заслонявшие таким образом гроб сверху; четвертая ось лежала горизонтально 
вдоль ямы, покоясь на колесах; третье колесо, наконец, лежало в северной половине могилы на крышке гроба. За неимением консервирующих средств взята лишь в обломках одна ось (фраза не вошла в текст статьи. - Б. $P$.).

На дне ямы, ближе к восточной стенке, сохранились остатки деревянного гроба, в котором лежал скелет женщины в вытянутом положении на спине, головой к ЮВЮ (опечатка исправлена в тексте статьи на «ЮЗ». Правильней ЮЮЗ - БР). Между головным концом гроба и южной стенкой могилы стоял треснувший глиняный сосуд <шаровидной формы, высотой $27 \mathrm{~cm}>$. Рост костяка $1,53<\mathrm{M}>$. Рядом с левым плечом, в гробу, $2<$ два небольших $>$ глиняных сосудика $<$ с округлым дном, грубой ручной работы, без орнамента $>$. В юго-западном углу гроба, рядом с глиняным сосудиком, лежало в кучке: <круглое> алебастровое пряслице, осколок бронзового зеркала, четыре деревянных чурка (чурки) и кучка желтого порошкообразного вещества.

$22 / 23$

Между левой рукой и тазом - кусок мела и кусочек желтоватого вещества. Рядом с правым коленом клинок железного ножа. У левого бедра 2-ая кучка желтого порошкообразного вещества. Гроб имел форму прямоугольного ящика.

Длина гроба $1,82<_{\mathrm{M}}>$, ширина в головах $0,60<\mathrm{M}>$, ширина в ногах $0,50<\mathrm{M}>$, высоту удалось установить до $0,18<\mathrm{M}>$. Толщина боковых дощечек 0,8 см., порода - липа. Толщина крышки 0,5 см. Толщина концевой головной дощечки 1 см., порода липа. Мест скреплений наблюсти (заметить) не удалось. От дна замечены (найдены) незначительные следы поперечных дощечек и на них остатки продольных, очень тонких.

В том же архивном деле сохранился полевой дневник Пауля Рау, заметки и зарисовки в котором не только дают дополнительную чрезвычайно ценную информацию, но и свидетельствуют о высоком уровне полевых исследований и скрупулезной фиксации ценной информации, которые были присущи автору дневника. Бо́льшая часть дневниковых заметок к схематическим наброскам сделана на немецком языке и по какимто причинам не вошла в текст отчета, хотя и содержит описание важных для понимания всей конструкции и обряда погребения деталей. Публикуемые страницы дневника сопровождаются прочитанными записями, которые для удобства пронумерованы и собраны в таблицу с параллельным переводом на русский язык ${ }^{5}$.
В отличие от авторов публикаций, автора раскопок можно поправить, кажется, только в одной неверной интерпретации. Пауль Рау отмечает, что в погребении были найдены три колеса и четыре оси, у которых перед погребением были отрублены по одному стержню для насадки колеса (рис. 2,1). На самом деле осей было всего две. Если попытаться соединить самую длинную ось 1 с самой короткой 4-й, мы получим ось А с длиной плеча около 1,8 м (рис. 2,2A). V-образный косой поруб в центральной части плеча мог образоваться при обычном в таком случае нанесении ударов топором с двух сторон. Ось Б, образованная соединением 2-й (с насаженным колесом) и 3-й (с реконструированным автором положением колеса), располагается симметрично оси А (рис. 2,2Б). Расстояние между колесами в этом случае составит около 1,92,0 м, что соответствует расстоянию между колесами повозки из Пятого Пазырыкского кургана [Грязнов, 1955, с. 31] и колесниц Китая от эпохи бронзы [Wagner, 2004, S. 110, Abb. 3; S. 111, Abb. 4] до ханьских [Liu Yonghua, 2002, p. 8].

В оси А выдолблены пять сквозных прямоугольных отверстий, часть которых сделана под дроги, скрепляющие между собой оси повозки, в оси Б такое отверстие одно, оно точно соответствует отверстию на оси A, верхняя часть которого разрушена (рис. 2,2, левая часть плеча). Несмотря на то что на вторую и четвертую оси колеса были насажены, стержни осей, как отмечал Пауль Рау, сохранились четырехгранными, что свидетельствует о том, что они не были в употреблении [Рау, 1929, с. 22]. Недоструганные стержни, не выдолбленные под дроги отверстия, три колеса, вместо четырех, отсутствие в могиле частей кузова и дышла - все это говорит о том, что детали повозки были положены в могилу в процессе их изготовления.

Непонятно, почему в публикации В.М. Клепикова реконструировано расположение колес «на провалившемся перекрытии» [Клепиков, 2017, с. 21]. В последовательном описании заполнения Пауль Рау отмечает, что разрозненные сучья [перекрытия], встречавшиеся в верхней части заполнения ямы, лежали «ближе к горизонту сплошным слоем будучи вдавлены в промежутки между колесами и осями, 
заслонявшими гроб» [Рау, 1929, с. 22]. На поперечном сечении могильной ямы в дневнике, обозначенном «Разрез» ${ }^{6}$ (рис. 1а, 13), и в отчете (рис. 3,3 ) отчетливо видно, что оси два и четыре, на стержни которых были надеты колеса, установлены наклонно - так, что их нижние концы легли на западную стенку рамы и сильно деформировали ее, а колеса только перекрывали раму с погребенной, но не лежали на ней. На раме горизонтально лежит только третье колесо, частично перекрывающее восточную стенку рамы в северной части, где стенка деформирована слабо (ср. сечение «гроба» на рис. 3,3).

В публикациях также искажена система крепления спиц в ступице. В машинописном тексте отчета Пауля Рау этот узел конструкции колеса не описан, но на рисунке в публикации И.В. Синицына появляется схема крепления спиц в ступице [Синицын, 1947, с. 76, рис. 49, справа внизу], которой нет на приложенных к отчету перебеленных на ватман рисунках (ср.: рис. 2,1, 3,1,3). Не исключено, что И.В. Синицын видел дневник Пауля Рау, но воспроизвел его зарисовку с существенным искажением. Описание вставленных в ступицу клиновидно зауженных концов спиц (всадов) на листе 107 архивного дела сопровождается карандашным наброском в правом нижнем углу, где хорошо видно, что тонкие концы спиц доходят до втулки, прорезая ступицу насквозь (рис. 16,24). Аналогично устроено крепление спиц в сравнительно хорошо сохранившейся ступице колеса из погребения 3 кургана 3 у хутора Антонов в междуречье Волги и Дона (рис. 4,3) [Мамонтов, 1994, c. 24-25, рис. 5,3]. По описанию П.Д. Степанова, концы спиц были видны внутри ступицы колеса из Сусловского кургана 1 [Степанов, 1925, с. 77]. Такая конструкция технически не рациональна: сила трения ступицы об ось возрастает, а сама ступица делается более хрупкой. Она возможна в двух случаях: или в ступицу дополнительно вставлялась металлическая втулка, как это делалось на колесах китайских колесниц [Liu Yonghua, 2002, p. 17, fig. 3; Миняев, Сахаровская, 2007, с. 132, 135, рис. $4,3,4]$, или повозка изначально не предназначалась для езды и изготавливалась только для погребального церемониала. Мне неизвестны металлические втулки в сарматс- ких погребениях с деталями повозок, и я рискну предположить, что здесь речь может идти о втором варианте. Не исключено также, что в погребения укладывались отдельные детали старых повозок, чаще всего пара колес - с протертыми до спиц ступицами, как предположил П.Д. Степанов [Степанов, 1925, c. 77], или колеса, из которых изымали годные металлические детали, или, как в погребени у с. Меркель, не доделанные до конца части повозки.

В небольшой заметке о сарматских повозках П.М. Кожин подробно остановился на деталях повозки из с. Меркель, опубликованных И.В. Синицыным. Отметив примитивную и грубую форму осей, не соответствующую совершенной форме колес, он предположил, что колеса при вращении на четырехгранных осях создавали бы непрерывную резкую тряску экипажа [Кожин, 1969, с. 93-94]. Предположение тем более странное, что автор неоднократно ссылается на описание Пауля Рау в передаче И.В. Синицына, где отмечено, что стержни осей не были доделаны. А в следующем абзаце прямо указывает на то, что повозки могли быть изготовлены специально для погребального ритуала [Кожин, 1969, с. 94]. Там же опровергаемое дневниковой зарисовкой и комментарием (рис. 1a,17) утверждение П.М. Кожина о том, что на стержнях осей нет отверстий для чеки.

По дневниковой зарисовке Пауля Рау, при соблюдении общих принципов конструкции ступицы колес имели необычную форму. Дневникового описания ступиц нет, сохранился только их схематичный поперечный разрез. Утолщенная часть ступицы, в которую вставлялись спицы (они обозначены на схеме четырьмя штрихами, рис. 1б,15), к внешнему концу сужается, образуя длинную втулку. На внешнем конце ступицы в противовес массивной центральной части с утолщением к центру оси обычно делалось утолщение, которое вместе с длинной втулкой обеспечивало устойчивость колеса и уменьшало амплитуду его колебания в вертикальной плоскости при движении (рис. 4,2,4). К сожалению, внешний конец ступиц повозки из погребения у с. Меркель не сохранился, судить о его форме мы не можем. Необычной у них была форма центральной части ступицы - сторона, обращен- 
ная к центру оси, была не плоской, а полукруглой, хотя у сохранившихся ступиц она плоская (рис. $4,2,3$ ) или слабовыпуклая (рис. 4,5 ). Вероятно, эта часть детали также не была окончательно обработана. У всех осей угол перехода плеча в стержень скруглен, что минимизировало вероятность поломки оси в этой точке (рис. 2,1). На схеме колесо плотно насажено на стержень - так, что ступицы примыкают к широкой части плеча, при этом вращаться на стержне оси, который к плечу становится прямоугольным в сечении, колесо просто не могло. Как решалась эта проблема - видно на ступицах колес повозки из Пятого Пазырыкского кургана. Обращенная к центру оси часть втулки воронковидно расширяется, что позволяет ступице, сохраняя круговое движение вокруг оси, вращаться этой частью вокруг прямоугольной детали (рис. 4,5). Необходимостью такого воронковидного расширения продиктован большой диаметр этой части ступицы.

Заклад могилы, но совершенно другого вида был исследован Поволжской археологической экспедицией в 1974 г. в кургане 5 могильника Кривая Лука VIII в Астраханской области, где колеса закрывали вход в подбой. Обе публикации этого комплекса фрагментарны и не верны в деталях, поэтому я счел возможным привести здесь его описание и план (рис. 5) по отчету ${ }^{7}$ [Федоров-Давыдов и др., 1975 , с. 70-73, рис. 67-69].

\section{Погребение 15 (впускное)}

Яма погребения размерами 2,2 × 2,3 м выявлена на глубине 378 от ЦК, к востоку от погребения 13. Западный борт ямы на глубине -422 от ЦК имел ступеньку шириной 30 см, вырытую в материковом песке. На ступеньке найдены бронзовый втульчатый трехгранный наконечник стрелы и сильно окислившийся железный наконечник. Ступенька спускается до глубины -452 от ЦК. На этой глубине яма имеет размеры $2,25 \times 1,3$ м. Яма ориентирована по линии северо-запад - юго-восток. В центре ямы в деревянном гробу совершено погребение. На глубине -424-442 от ЦК, в юго-западном углу ямы и вдоль ступеньки расчищены отпечатки ступиц четырех колес, положенных, очевидно, на край ступеньки и частично перекрывавших западную стенку гроба. В гробу из деревянных плах шириной 4-5 см совершено парное захоронение женщины и подростка. Длина гроба 1,90 м, ширина 0,60-0,75 м. В центре гроба лежал костяк женщины, обернутый в бересту. Костяк хорошей сохранности. Все кости скелета сохранились in situ и фиксировали вытянутое на спине положение погребенной, ориентированной головой на юго-восток. Череп лежал на затылочной кости со склонением к правому плечевому суставу. Правая рука погребенной вытянута вдоль корпуса, плотно прижата к нему. Кисть правой руки находилась в области правого тазобедренного сустава. Левая рука была слегка отодвинута от корпуса, согнута в локте. Кисть левой руки лежала на левом тазобедренном суставе. Ноги погребенной вытянуты, параллельны. Стопы вытянуты и направлены в разные стороны. Береста, в которую была обернута погребенная, лучше всего сохранилась на стопах.

На костях грудной клетки, острием к левому плечу, лежал костяной кочедык с отверстием в утолщенной части. На правом крыле таза найдена литая бронзовая круглая пряжка с язычком. У левого плечевого сустава обнаружен пучок железных черешковых трехгранных стрел. Стрелы очень плохой сохранности. Взять их не удалось. Правая кисть погребенной покоилась на рукояти короткого железного меча с прямым перекрестием и серповидным (?) навершием. Под лучевыми костями обеих рук находились истлевшие железные предметы крестовидной формы.

В северо-восточном углу гроба, вдоль правого бедра погребенной, лежал костяк подростка. Костяк сильно сжат, буквально втиснут в гробовину. Сохранность костяка удовлетворительная; все кости скелета находились in situ и фиксировали вытянутое на спине положение погребенного, ориентированного головой на юго-восток. Череп лежал на затылочной кости. Руки были плотно прижаты к корпусу и слегка согнуты в локтях. Кисти рук находились на тазовых костях. Ноги вытянуты, соединены в коленях и пяточных костях. Стопы вытянуты. У правой голени погребенного лежали железные черешковые трехгранные наконечники стрел. Между бедренными костями обнаружена железная массивная пряжка. На запястьях были найдены браслеты из мелких пастовых бусинок. Под черепом, в области шеи обнаружено ожерелье из пастовых и гешировых бусин. Удалось проследить порядок бусин: 5-6 гешировых пастовая - 5-6 гишеровых...

В изголовье гроба, у южной стенки подбоя, лежали кости ног и лопатка барана, а в юго-западном углу, на глубине -435 от ЦК (очевидно, на подсыпке) стоял лепной орнаментированный сосуд с узким горлом, слегка отогнутым венчиком и ручкой. Тулово сосуда раздутое, сужающееся ко дну.

При расчистке женского костяка, на 20 см выше него, в области грудной клетки найдены фрагменты железной, сильно окислившейся пряжки. 
Это парное захоронение относится к сарматскому периоду и датируется III-II вв. до н.э. Парное захоронение сарматского периода (костяки 1 и 2) нарушило, очевидно, более раннее подбойное захоронение, ориентированное по линии запад - восток.

Остановлюсь на нескольких важных деталях захоронения, которые требуют безусловной корректировки, и прежде всего - на форме могильной ямы. В тексте отчета она описана как «яма». В.М. Клепиков определяет ее как «прямоугольную яму» [Клепиков, 2017, с. 21]. В статье Ф.Р. Балонова форма ямы не названа, но в таблице она отмечена как яма с подбоем [Балонов, 1980 , с. 81 , табл. 2] ${ }^{8}$. Информация об устройстве ямы была получена Ф.Р. Балоновым от руководителя экспедиции, имевшего основания для реконструкции, и он описывает ее как катакомбную, или яму с подбоем [Балонов, 1980, 83-84, примеч. 7 и 43]. Сооружение могильной ямы погребения 15 в мешаном заполнении сложной связки из шести ям не позволяло проследить конструкцию подбоя, но некоторые детали говорят именно о такой ее форме. Во-первых, ступенька в яме фиксировалась вдоль одной из длинных сторон - юго-западной. Считать частью второй ступеньки поверхность перемычки между погребениями 15 и 16 не позволяет то обстоятельство, что рама и погребенный сдвинуты к северо-восточной, задней стенке, что обычно для подбоев. Глубина дна ямы от уровня ступеньки составляет $0,3 \mathrm{M}$, что необычно мало для ямы с заплечиками. Ни на «заплечиках», ни в заполнении не были обнаружены какие-либо следы перекрытия, что странно для неограбленной могилы. Наконец, расположение колес на ступеньке вдоль длинной стенки ямы обычно для заклада подбоя.

Из необычных деталей отмечу устройство рамы не на дне ямы, а в специально подготовленном углублении (рис. 5,1 , разрез А-A), стенки которого обложены деревянными плахами шириной 4-5 см, составляющими раму [Федоров-Давыдов и др., 1975, рис. 290-293].

В.М. Клепиков, основываясь на тексте отчета, где упомянуты ступицы четырех колес, категорически не согласен с Ф.Р. Балоновым, упоминающим в начале описания три колеса (с вопросом), а потом, после сопостав- ления параметров сохранившихся отпечатков, предположившим, что колес, возможно, было не три, а два [Балонов, 1980, с. 77]. Ни чертеж погребения (рис. 5,1), ни полевые фотографии [Федоров-Давыдов и др., 1975, рис. 287-289] не позволяют говорить о четырех ступицах. Я попытался вновь осуществить реконструкцию колес, использовав возможности компьютерной графики. Результаты еe (рис. 5,2) заставляют присоединиться к предположению Ф.Р. Балонова о двух колесах разного диаметра. При том что отпечатки колес можно было фиксировать с изрядной долей условности, реконструированные размеры колес очень близки: у Ф.Р. Балонова 0,92-1,04 до 1,30 м [Балонов, 1980, с. 77] или 100 (130) <см> [Балонов, 1996, табл. 2, 12], и 0,9 м (меньшее) и 1,15 м (большее) колеса по реконструкции автора. Из-за сильной деформации и сохранности колес в виде тонкой прослойки тлена нельзя, впрочем, исключить ошибки в расчетах. Колеса в Кривой Луке, как в большинстве захоронений, когда их размер восстанавливается точно, могли быть одного диаметра.

Подбой, как отмечалось выше, был сооружен в заполнении ранних погребений, его обрушение произошло, вероятно, вскоре после захоронения, из-за чего установленные под углом колеса разломались, легли горизонтально, а отдельные их части переместились, судя по плану, в южном направлении

Для заклада подбоя использовали обычно два колеса, которые при большом диаметре перекрывали его на всю длину. Заклад подбоя тремя колесами известен один - погребение 13 кургана 4 у с. Политотдельское [Клепиков, 2017, с. 22, 27, рис. 5]. Три колеса из погребения у с. Меркель (рис. 3,1) или четыре колеса из погребения 12 в кургане 17 у с. Быково [Смирнов, 1960, с. 220 , рис. 19,2a,б) найдены не в подбойных, а в прямоугольных ямах. И только в прямоугольных ямах вместе с колесами, даже если колесо было одно [Смирнов, 1959 , с. $268-270$, рис. 24,1$]$, всегда находили детали осей или кузовов повозок, которых нет в закладах подбоев.

Анализ конструкции могильных ям и деталей повозок, найденных в двух описанных погребениях, позволяет сделать некоторые выводы. Во-первых, можно говорить о существовании в раннесарматское время на тер- 
ритории Нижнего Поволжья двух типов могильных сооружений, в которые помещались повозки, - простых ям и ям с подбоями.

В первые, помимо колес (от одного до трех), иногда укладывали отдельные части кузова и иные части повозки. В погребениях подбойных для перекрытия устья подбоя использовали только колеса. За исключением одного случая, колес было два, и за счет большого диаметра они закрывали устье по всей длине.

Особенности обработки отдельных узлов и деталей повозок, помещавшихся в погребения, дают возможность предполагать, что для погребальной церемонии использовали части старых повозок или их не доделанные до конца, может быть бракованные на стадии изготовления, части.

Поиски аналогий самой идее помещения повозки в могилу или замещения ее отдельными частями, среди которых обязательны колеса как самый зримый символ повозки, заставляют обратиться к захоронениям Центральной Азии и Алтая, где есть свидетельства генезиса двуосных повозок [Гук, Николаев, 2012, с. 454]. Одноосные повозки, появляющиеся в Восточноевропейских степях в более позднее время, связаны своим происхождением с этим же регионом. Их сходство с повозками из раннесарматских курганов, как и отличия от транспортных средств предшествующего времени, заслуживают специального исследования. Этому, а также времени, путям и механизму распространения традиции из восточных в западные степи Евразии будет посвящена вторая часть представленной здесь работы.

\section{Продолжение следует...}

\section{ПРИМЕЧАНИЯ}

\footnotetext{
${ }^{1}$ Работа выполнена при поддержке программы фундаментальных научных исследований государственных академий наук на 2013-2020 годы в рамках базовой темы НИР «Изучение межкультур-
}

ных взаимодействий населения Нижнего Дона с древнейших времен до нового времени», № гос. регистрации 01201354248.

The work was supported by the program of fundamental scientific research of state academies of sciences for 2013-2020 in the framework of basic research topic "Study of the Intercultural Interactions of the Population of the Lower Don from Ancient Times to the New Age", state registration no. 01201354248.

${ }^{2}$ На карте [Клепиков, 2017, с. 23, рис. 1] с. Меркель нанесено неверно. От с. Верхняя Добринка оно находится не к юго-западу, а к северо-востоку, на p. Карамыш, примерно в 1,5 км от границы Саратовской области.

${ }^{3}$ Орфография и пунктуация текста отчета сохранены, дополнения И.В. Синицына выделены угловыми скобками, замена им отдельных слов - круглыми скобками, а измененные слова - курсивом.

${ }^{4}$ Правильно: стержни их были вставлены в колеса. Опечатка в отчете Пауля Рау повторена в статье И.В. Синицына [1947, с. 76].

5 Заметки 2, 9, 13 и 14 в дневнике написаны по-русски. Неразборчивый почерк рукописных документов Пауля Рау создает определенные трудности для чтения, на что уже обращалось внимание [Детлова и др., 2019, с. 226-227], не говоря о специфике диалекта жителей АССР Немцев Поволжья. Прочтение дневниковых заметок и их перевод на русский язык - заслуга Frau Dr. Adele Bill (Universität Heidelberg), которой я выражаю искреннюю признательность за неоценимую помощь. Я также пользуюсь случаем выразить глубокую благодарность Herr Dr. Anatoli Nagler (Deutsches Archäologisches Institut), с которым обсуждались и уточнялись некоторые формулировки и термины русского текста.

${ }^{6}$ То, что на схеме в дневнике и в отчете названо разрезом, является схемой расположения частей повозки при виде с юго-запада, совмещенной с разрезом, в котором показаны: первая ось, ступицы колес и рама («гроб») на дне ямы. Третья ось показана вертикально, а четвертая перекрывает вторую, чего в разрезе быть не может.

${ }^{7}$ В тексте отчета опущены ссылки на рисунки в альбоме и отсылка к номерам находок на плане погребения.

${ }^{8}$ Многочисленные опечатки и неточности в статье, допущенные редакцией, не выславшей автору корректурный оттиск, исправлены им в приложении к диссертации [Балонов, 1996, табл. 2]. 


\section{ИЛЛЮСТРАЦИИ}

\section{Таблица. Заметки Пауля Рау на полевых чертежах деталей повозки}

\section{Table. Notes by Paul Rau to his field drawings of vehicle parts}

\begin{tabular}{|c|c|c|}
\hline 1 & $\begin{array}{l}\text { neue, ungebrauchte Achse / Achse im Zuschnitt des drit- } \\
\text { ten Grabes }\end{array}$ & $\begin{array}{l}\text { новая, неиспользованная ось / ось в разрезе третьей } \\
\text { могилы } 1\end{array}$ \\
\hline 2 & - & толщ[ина] 0,07 [м] \\
\hline 3 & Nabe & Ступица \\
\hline 4 & schräg durchgehauen im Altertum & косо перерублено в древности \\
\hline 5 & $\begin{array}{l}\text { 3. Achse. Höhe der Achsenbrust 16,5 cm } \\
\text { Unten abgehauen } \\
\text { Dm. des Achsenschenkels } 7 \mathrm{~cm}\end{array}$ & $\begin{array}{l}\text { 3-я ось. Ширина плеча оси } 16,5 \text { см. } \\
\text { Внизу отрублено. } \\
\text { Дм. окончания оси } 7 \text { см }\end{array}$ \\
\hline 6 & ins.(?) $<\ldots>$ Aschsen(?) & ins.(?) <нрзб.> зола(?) \\
\hline 7 & 2. Achse & 2-я ось \\
\hline 8 & Birkenholz. Reisig & Березовые сучья. Хворост \\
\hline 9 & - & $<$ нрзб.> пятно ${ }^{2}$ \\
\hline $9 \mathrm{a}$ & 3. Rad[es] & 3-е колесо \\
\hline 10 & Etwa 0,40 über Bodenniveau im Hügelaufschnitt & Около 0,40 [м] над уровнем земли в разрезе кургана ${ }^{3}$ \\
\hline 11 & $\begin{array}{l}\text { Länge der Speichen 0,45. } \\
\text { Durchschnitt }-3,5 \mathrm{~cm} \times 2 \mathrm{~cm} \\
\text { Eiche }\end{array}$ & $\begin{array}{l}\text { Длина спиц } 0,45[\mathrm{M}] . \\
\text { Сечение } 3,5 \mathrm{~cm} \times 2 \mathrm{~cm} . \\
\text { Дуб }\end{array}$ \\
\hline 12 & 4. Achse & 4-я ось \\
\hline 13 & - & Разрез [3-B] \\
\hline 14 & - & Отодвинуть к югу на 20 см \\
\hline 15 & 2. Achse & 2 -я ось \\
\hline 16 & $\begin{array}{l}\text { Querschnitt der Nabe mit dem Achsenschenkel, der } \\
\text { nicht rund, sondern rechteckig in der Nabe steckt }\end{array}$ & $\begin{array}{l}\text { Поперечный разрез ступицы с осью, которая не } \\
\text { круглая, а прямоугольная, вставленная в ступицу }\end{array}$ \\
\hline 17 & Achsensplitter mit Lohnenschlitz & Обломок оси с намеренно сделанным отверстием ${ }^{4}$ \\
\hline 18 & gemeißeltes Loch & Выдолбленное отверстие \\
\hline 19 & $\begin{array}{l}\text { Achsenbrust, Länge } 63 \mathrm{~cm} \text {, Höhe } 15 \mathrm{~cm} . \\
\text { Unten stark angekohlt }\end{array}$ & $\begin{array}{l}\text { Плечо оси, длина } 63 \text { см, высота } 15 \text { см. } \\
\text { Внизу сильно обуглено }\end{array}$ \\
\hline 20 & abgehauener Achsenschenkel, den Grund berührend & Обломанное окончание оси, касается дна [ямы] \\
\hline 21 & $\begin{array}{l}\text { Dm. des Achsenschenkels } 7 \mathrm{~cm} . \\
\text { Eiche }\end{array}$ & $\begin{array}{l}\text { Дм. окончания оси } 7 \text { см. } \\
\text { Дуб }\end{array}$ \\
\hline 22 & $\begin{array}{l}\text { 4. Achse-Länge des gemeißelten Loches } 6 \mathrm{~cm} \text {. Breite } 4 \\
\text { cm. Darin Holzreste - emporstrebend, senkrecht zur } \\
\text { Achse. Es ist die Achse des südlichen Rades. Höhe der } \\
\text { Achsenbrust } 17,5 \mathrm{~cm} \text {. Westlich nach unten gesenkt, der } \\
\text { westliche Achsenschenkel abgehauen. Das Loch scheint } \\
\text { die Mitte einzunehmen }\end{array}$ & $\begin{array}{l}4-я \text { ось - длина выдолбленного отверстия } 6 \text { см, ши- } \\
\text { рина } 4 \text { см. Из него [вверх] торчат остатки дерева } \\
\text { перпендикулярно оси. Это ось южного колеса. Вы- } \\
\text { сота плеча оси } 17,5 \text { см. Западная часть опустилась } \\
\text { вниз, западное окончание оси отломано. Отверстие, } \\
\text { видимо, было в середине }\end{array}$ \\
\hline 23 & $\begin{array}{l}3 \text { Rad, unter dem nördlichen. senkrecht mit dem Ach- } \\
\text { senloh. Dm der Nabe } 23 \mathrm{~cm} . \text { Am } 4 \text { Teil des Nabenkrei- } \\
\text { ses } 7 \text { Speichen senkrecht Gänzlich zerfallen }\end{array}$ & $\begin{array}{l}\text { 3-е колесо, под северным [колесом]. Перпендику- } \\
\text { лярно отверстию оси. Дм. втулки } 23 \text { см. На 4-й час- } \\
\text { ти окружности ступицы [сохранились] } 7 \text { перпенди- } \\
\text { кулярных [ей] спиц. Полностью распались }\end{array}$ \\
\hline 24 & $\begin{array}{l}\text { Vom Radkranz hat sich nur eine unvollständige Felge } \\
\text { erhalten. Die Speichen waren an der Wurzel } \\
\text { schmal und steckten keilartig in der Nabe }\end{array}$ & $\begin{array}{l}\text { От обода колеса сохранилась только небольшая } \\
\text { часть. Спицы у корня [основания] клиновидно за- } \\
\text { ужены и вставлены в ступицу }\end{array}$ \\
\hline
\end{tabular}

Примечания. ${ }^{1}$ - на рисунке первой оси (рис. 1, вверху) под стержнем и справа от поруба на плече показаны спицы и ободья колес 2 и 3 , поверх которых она лежала; ${ }^{2}$ - вероятно, отпечатки спиц колеса на стенке могильной ямы; ${ }^{3}$ - над уровнем погребенной почвы $(?) ;{ }^{4}$ - выдолбленное отверстие для чеки, закрепляющей колесо на оси. 


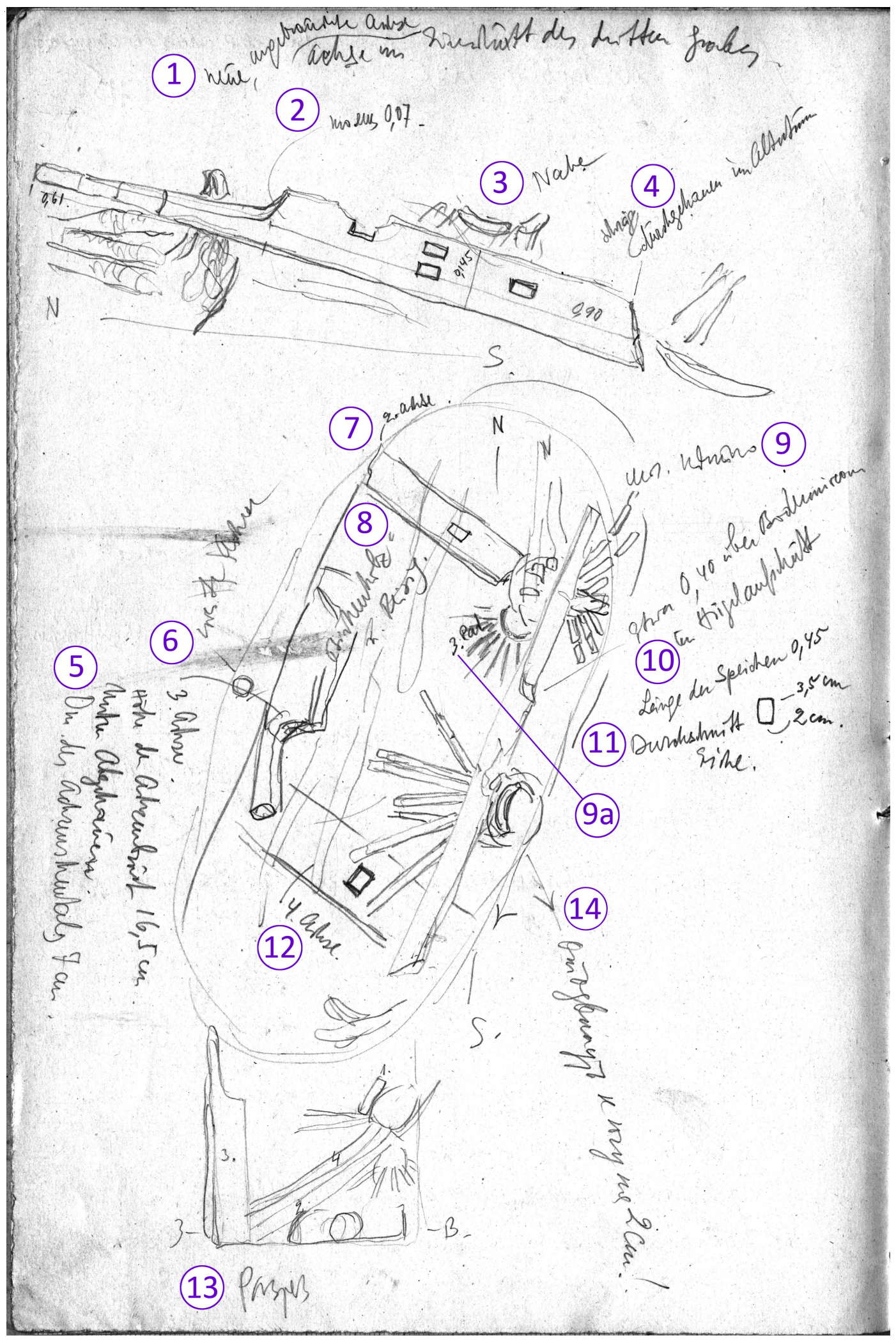

Рис. 1а. Дневник раскопок Пауля Рау 1929 года (Научный архив ИИМК РАН. Ф. 2. 1929, д. 149, л. 106 об.). Нумерация заметок на листах отчета проставлена Б.А. Раевым

Fig. 1. 1929 Paul Rau Excavation Diary (Scientific archive of the Institute for the History of Material Culture of the Russian Academy of Sciences. F. 2, 1929, no. 149, sheet 106 back side).

Numbering notes on copy' sheets by B.A. Raev 


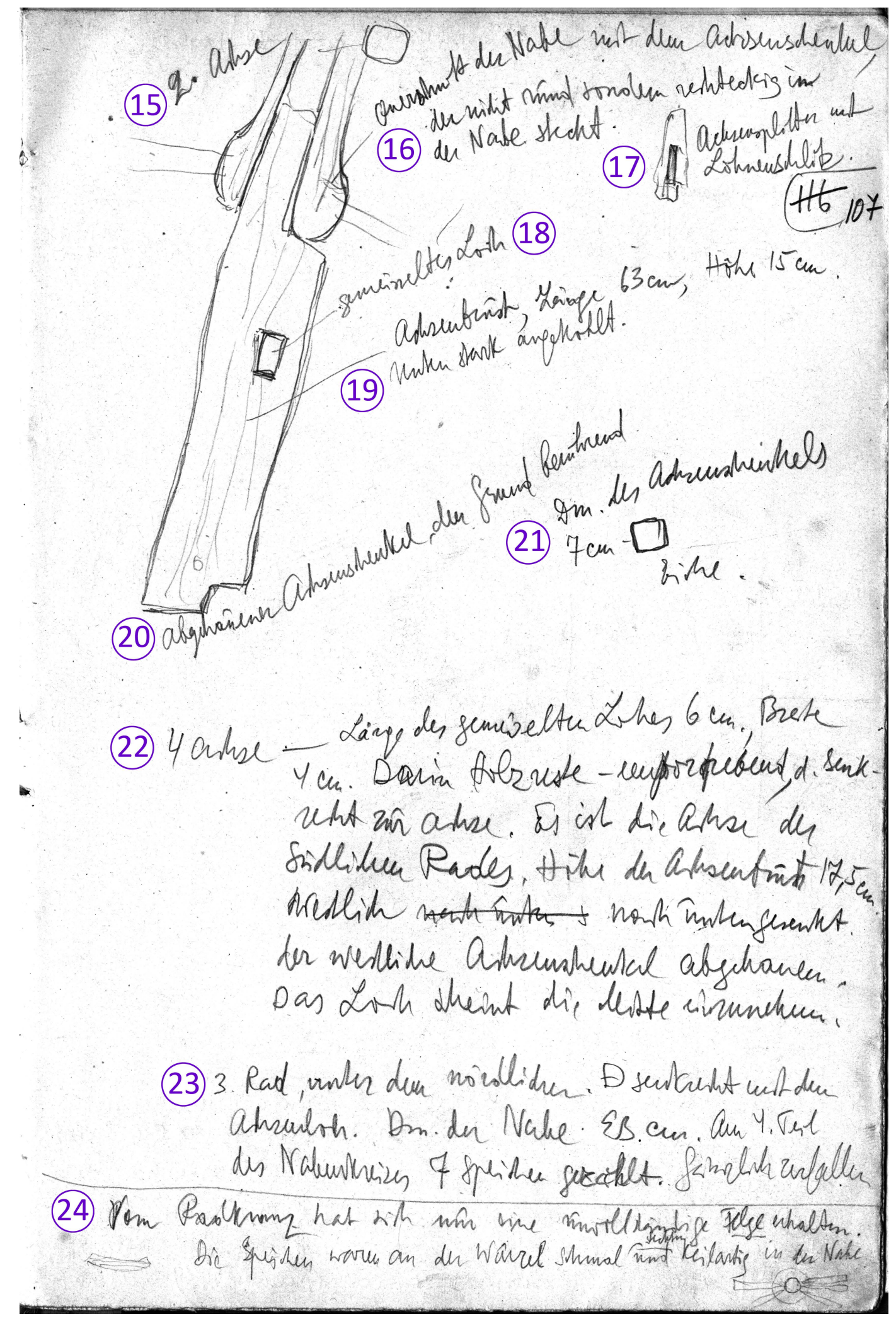

Рис. 1б. Дневник раскопок Пауля Рау 1929 года (продолжение; Ф. 2. 1929, д. 149, л. 107)

Fig. 1. 1929 Paul Rau Excavation Diary (continuation: Scholarly archive of the Institute for the History of Material Culture of the Russian Academy of Sciences. F. 2, 1929, no. 149, sheet 107) 
Б.А. Раев. Повозки в сарматских погребениях нижневолжских и нижнедонских курганов

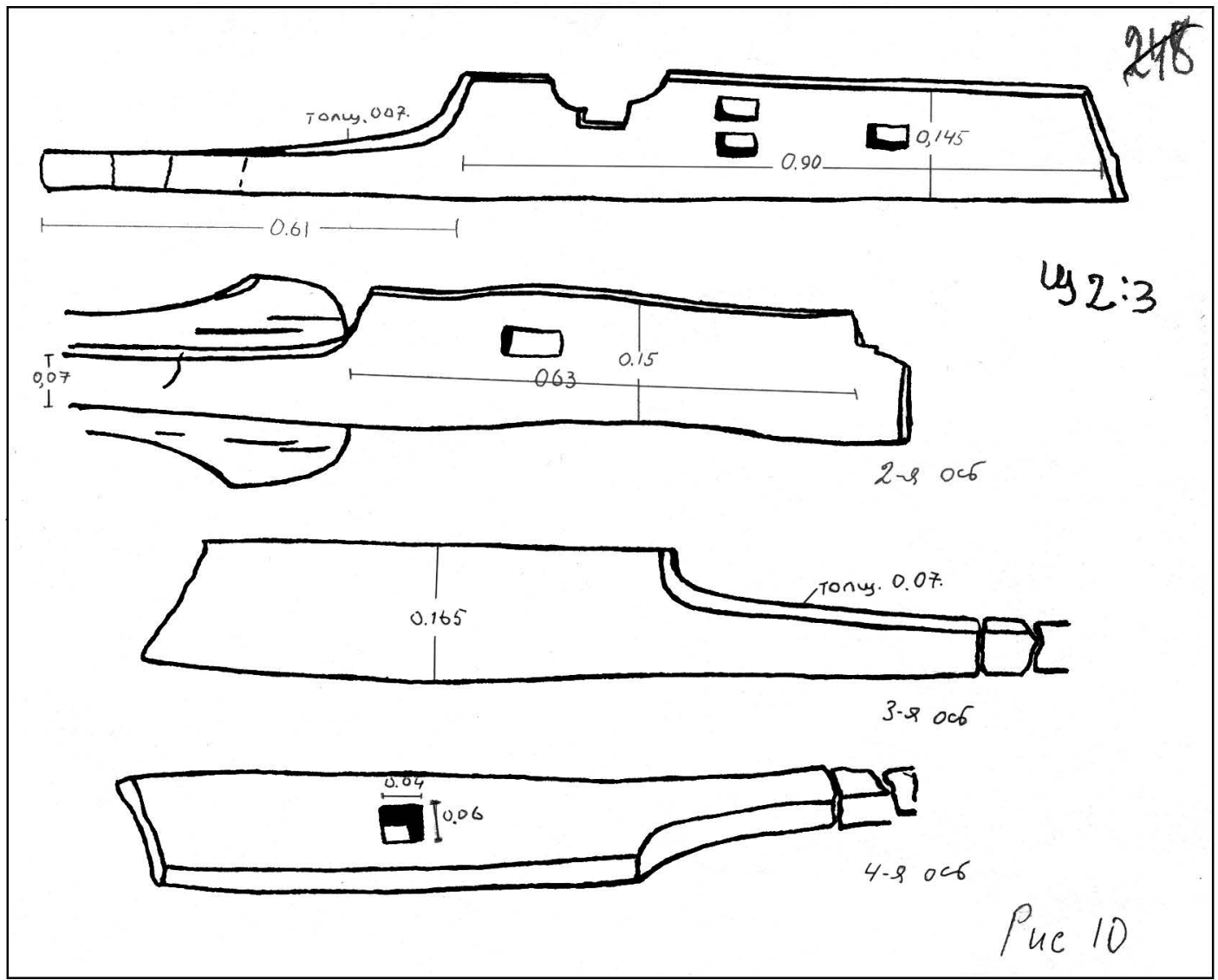

1

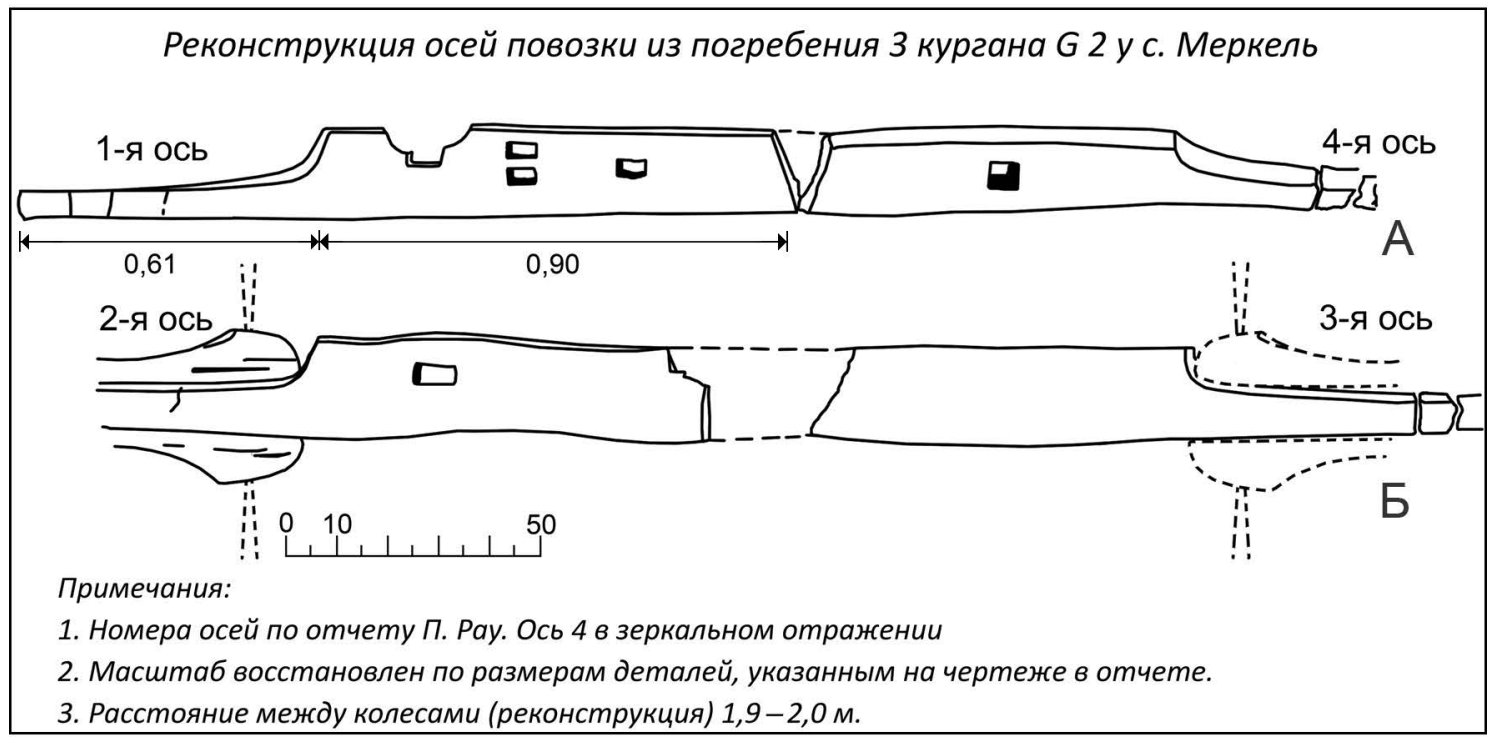

2

Рис. 2. С. Меркель, курган G2, погребение 3:

1 - оси повозок по полевому отчету Пауля Рау (Научный архив ИИМК РАН. Ф. 2. 1929, д. 149, л. 209);

2 - реконструкция устройства осей (компьютерная графика автора)

Fig. 2. Village of Merkel, kurgan G2, grave 3:

1 - vehicle axles according to the field report of Paul Rau (Scholarly archive of the Institute for the History of Material Culture of the Russian Academy of Sciences. F. 2, 1929, d. 149, 1. 209);

2 - reconstruction of the axles construction (computer graphics by the author) 
B.A. Raev. Wagons in Sarmatian Burials of the Lower Volga and Lower Don Kurgans
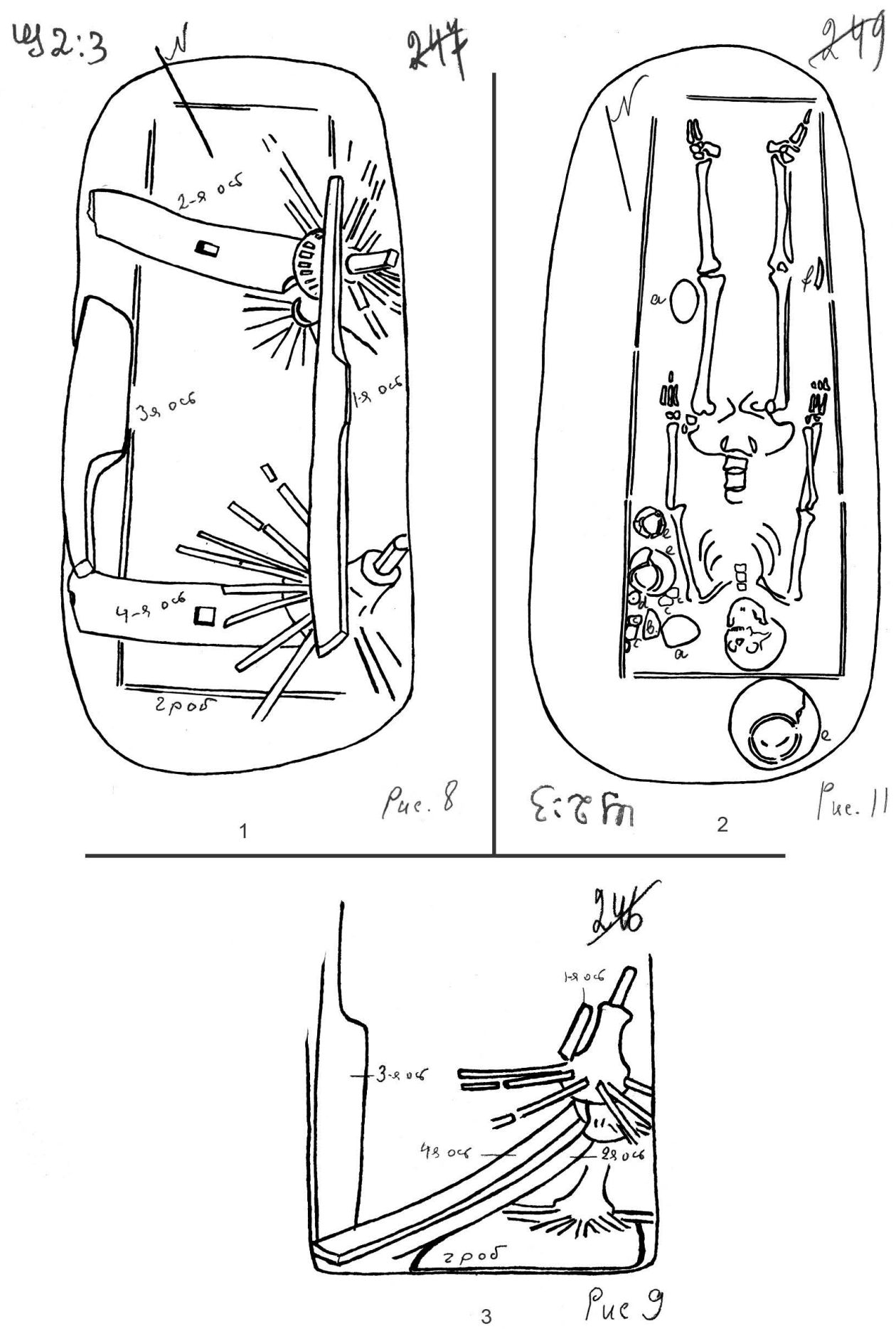

Рис. 3. С. Меркель, курган G2, погребение 3. Рисунки к полевому отчету Пауля Рау 1929 года:

1 - схема расположения частей повозки в яме погребения (Научный архив ИИМК РАН. Ф. 2. 1929, д. 149, л. 207); 2 - план погребения (Научный архив ИИМК РАН. Ф. 2. 1929, д. 149, л. 210);

3 - разрез (Научный архив ИИМК РАН. Ф. 2. 1929, д. 149, л. 208)

Fig. 3. Village of Merkel, kurgan G2, grave 3. Drawings for the Paul Rau report on excavations 1929:

1 - location of the vehicle parts in the grave pit (Scholarly archive of the Institute for the History of Material Culture of the Russian Academy of Sciences. F. 2. 1929, d. 149, 1. 207);

2 - plan of the grave (Scholarly archive of the Institute for the History of Material Culture of the Russian Academy of Sciences. F. 2. 1929, d. 149, 1. 210);

3 - cross-section (Scholarly archive of the Institute for the History of Material Culture of the Russian Academy of Sciences. F. 2. 1929, d. 149, 1. 208) 

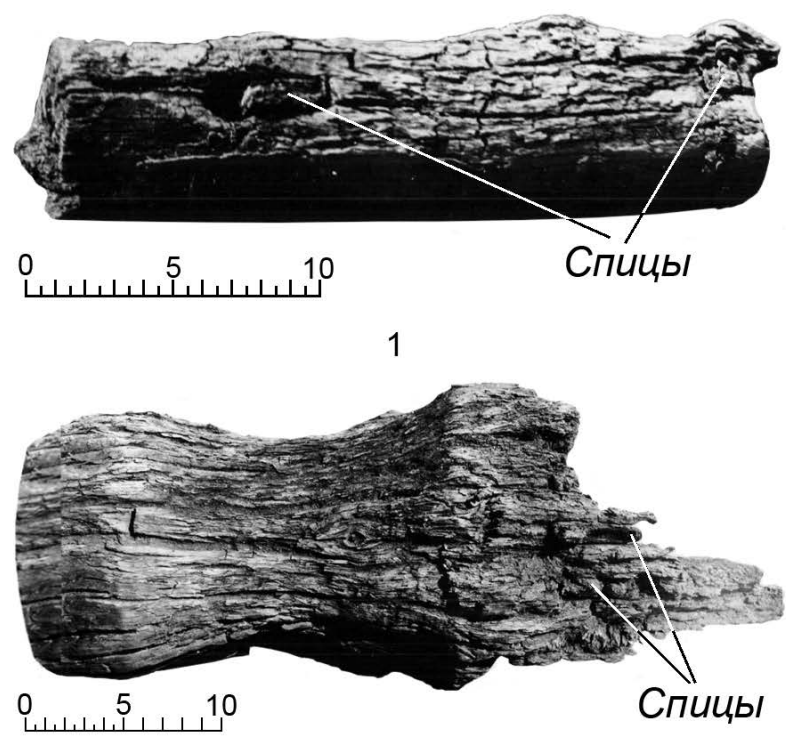

2
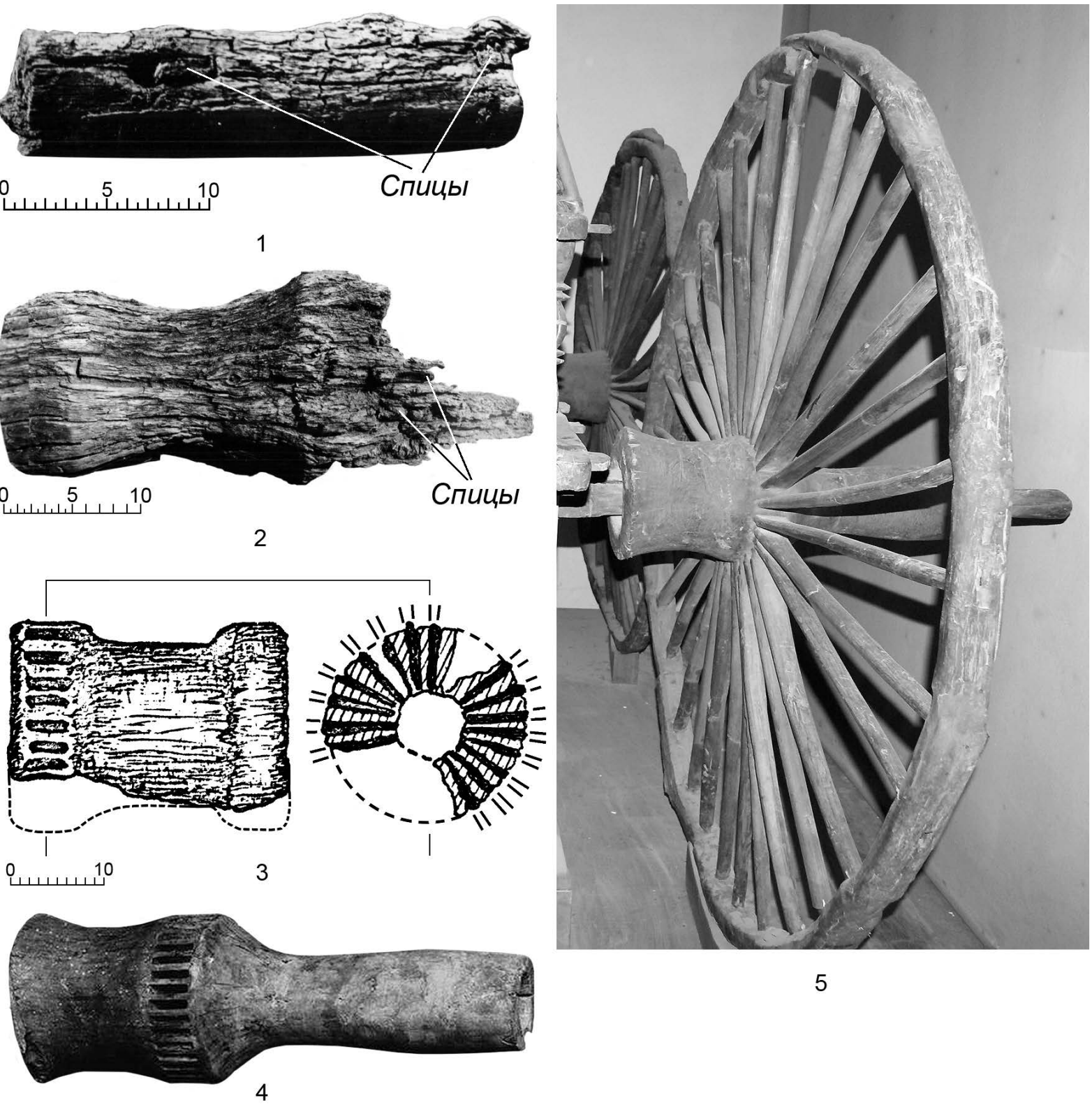

5

Рис. 4. Ступицы и ободья колес повозок из сарматских курганов и их аналоги:

1, 2 - часть обода колеса (1) и ступица (2), с. Политотдельское, курган 4, погребение 13 (по: [Комаров и др., 1990, рис. 54,1,2]); 3 - хут. Антонов, курган 3, погребение 3 (по: [Мамонтов, 1994, с. 25, рис. 5,3]);

4 - Пятый Пазырыкский курган (по: [Гук, Николаев, 2012, с. 455, рис. 1,2]);

5 - то же (архив Отдела археологии Восточной Европы и Сибири Государственного Эрмитажа)* (1-5: компьютерная графика автора)

Fig. 4. Wheel naves and rims of vehicles from Sarmatian kurgans and their parallels:

1, 2 - part of the wheel rim (1) and the same nave (2), Village of Politotdel'skoe, kurgan 4, grave 13

(after: [Komarov et al., 1990, fig. 54,1,2]); 3 - farmstead of Antonov, kurgan 3, grave 3 (after: [Mamontov, 1994, p. 25, fig. 5,3]); 4 - Fifth Pazyryk Kurgan (after: [Guk, Nikolaev, 2012, p. 455, fig. 1,2]);

5 - Fifth Pazyryk Kurgan (archive of the Department of Archeology of Eastern Europe and Siberia of the State Hermitage) * (1-5: computer graphics by the author)

Примечание. * - фотографии для печати были любезно предоставлены мне Николаем Николаевичем Николаевым (Отдел археологии Восточной Европы и Сибири Государственного Эрмитажа), которого я благодарю за интерес к моей работе и помощь в подготовке статьи. 


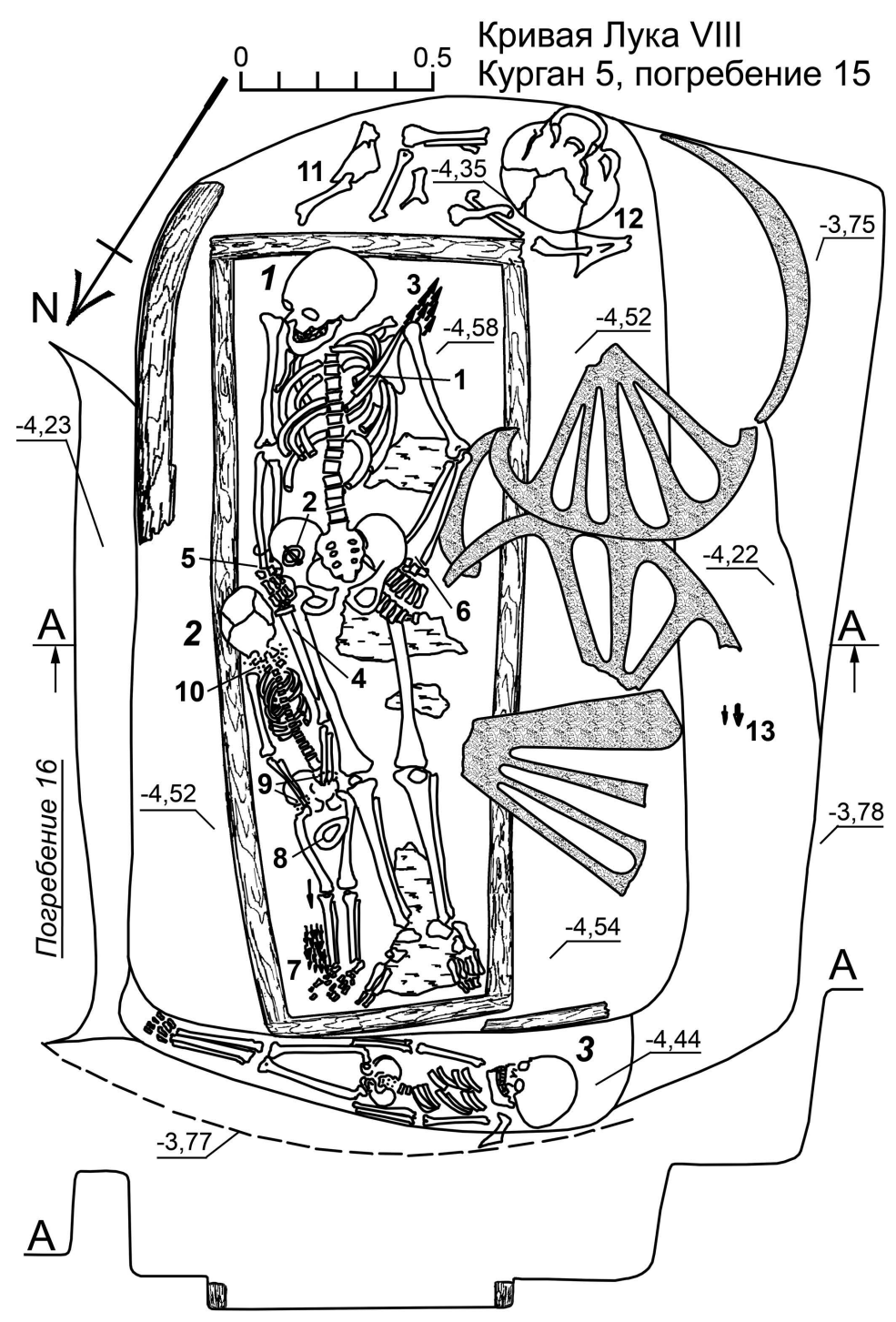

1. Кочедык

2. Пряжка

3. Наконечники стрел

4. Кинжал

5, 6. Железные предметы

7. Наконечники стрел
8. Пряжка

9. Браслеты из бус

10. Ожерелье

12. Сосуд

13. Наконечники стрел
11. Кости MPC

дерево - древесный тлен

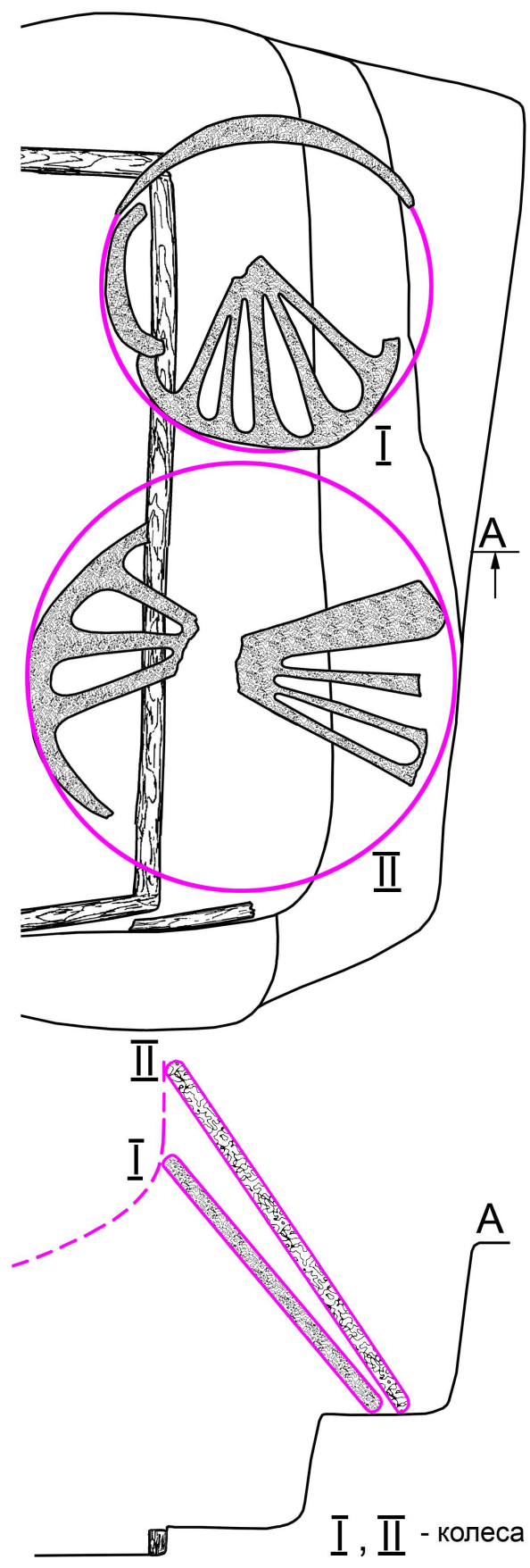

2

Рис. 5. Могильник Кривая Лука VIII, курган 5, погребение 15:

1 - план погребения (по: [Федоров-Давыдов и др., 1975, рис. 67];

2 - реконструкция расположения колес в могильной яме (1-2: компьютерная графика автора)

Fig. 5. Kurgan cemetery Krivaia Luka VIII, kurgan 5, grave 15:

1 - plan of the grave (after: [Fedorov-Davydov et al., 1975, fig. 67];

2 - the reconstruction of wheels location in the grave pit (1-2: computer graphics by the author) 


\section{СПИСОК ЛИТЕРАТУРЫ}

Балонов Ф. Р., 1980. Колесный транспорт сарматской эпохи // Археология Южной Сибири. Кемерово : Кемеров. гос. ун-т. С. 69-87.

Балонов Ф. Р., 1996. Культ коня и колесницы в скифо-сарматскую эпоху у народов евразийских степей и предгорий : дис. ... канд. ист. наук в форме доклада. СПб. : С.-Петерб. гос. ун-т. 29 с.

Грязнов М. П., 1955. Колесница ранних кочевников Алтая // Сообщения Государственного Эрмитажа. Вып. VII. C. $30-32$.

Гук Д. Ю., Николаев Н. Н., 2012. Повозка из Пятого Пазырыкского кургана // Культуры степной Евразии и их взаимодействие с древними цивилизациями. Кн. 2. СПб. : ИИМК РАН, Периферия. С. 454-457.

Детлова Е. В., Кузьминых С. В., Малов Н. М., 2019. П.С. Рыков и П.Д. Рау в зеркале переписки с учеными Западной Европы (А.М. Тальгрен, Г. Мергарт, Э.Х. Миннз, Т. Арне) // Археология Восточно-Европейской степи. Вып. 15. Саратов : Изд-во СГУ. С. 224-298.

Клепиков В. М., 2017. Погребения раннесарматской культуры Нижнего Поволжья с деталями повозки в закладе могильной камеры // Вестник Волгоградского государственного университета. Серия 4. История, Регионоведение. Международные отношения. Т. 22, № 3. С. 20-35. DOI: https://doi.org/10.15688/jvolsu4.2017.3.2

Кожин П. М., 1969. О сарматских повозках // Древности Восточной Европы. К семидесятилетию Алексея Петровича Смирнова. МИА. № 169. М. : Наука. С. 92-95.

Комаров А. М., Кузьмина О. В., Иванов А. Ю. 1990. Отчет о раскопках курганных могильников у с. Политотдельское (Николаевский район), Хохлачевский (Среднеахтубинский район), у хутора Молокановский (Октябрьский район), Казачий (Котельниковский район) и одиночного кургана у с. Песковатка (Калачевский район) в зонах строительства оросительных систем в Волгоградской области в 1989 г. Волгоград, 1990 // Архив ВОКМ. № 102.

Мамонтов В. И., 1994. Курганный могильник Антонов I / Древности Волго-Донских степей. Вып. 4. Волгоград : Перемена. С. 15-46.

Миняев С. С., Сахаровская Л. М., 2007. Ханьская колесница из могильника Царам // Археологические вести. Вып. 14. С. 130-140.

Рау П. Д., 1929. Отчеты о раскопках 1928 и 1929 гг. с дневником, чертежами, рисунками и фотографиями // Архив ИИМК РАН. Ф. 2. Оп. 1. № 149.

Синицын И. В., 1947. Археологические раскопки на территории Нижнего Поволжья. Саратов : Изд-во СГУ. 134 с.

Смирнов К. Ф., 1959. Курганы у сел Иловатка и Политотдельское Сталинградской области // Древности Нижнего Поволжья. МИА. № 60. М. : Изд-во Акад. наук СССР. С. 206-322.

Смирнов К. Ф., 1960. Быковские курганы // Памятники Нижнего Поволжья. МИА. № 78. М. : Изд-во Акад. наук ССCР. С. $169-268$.

Степанов П. Д., 1925. Изделия из дерева в курганах Сусловского могильника. В: Рыков П.С. Сусловский курганный могильник // УЗСаратГУ. Т. IV. Вып. 3. С. 76-81

Федоров-Давыдов Г. А., Дворниченко В. В., Малиновская Н. В., 1975. Отчет о раскопках курганов в урочище «Кривая Лука» в Черноярском районе Астраханской области в 1974 г. Москва, 1975. Т. 1-3 // Архив Астраханского музея-заповедника.

Liu Yonghua, 2002. Zhongguo Gu Dai Che Yu Ma Ju. Shanghai Shi : Shanghai ci shu chu ban she. 200 p.

Wagner M., 2004. Wagenbestattungen im bronzezeitlichen China. In: Fansa M., (Hrsg.) Rad und Wagen: Der Ursprung einer Innovation; Wagen im Vorderen Orient und Europa. Oldenburg-Mainz-Isensee : P. von Zabern. S. 107-122.

\section{REFERENCES}

Balonov F.R., 1980. Kolesnyi transport sarmatskoi epokhi [Wheel Transport of the Sarmatian Era]. Arkheologiia Yuzhnoy Sibiri [Archeology of Southern Siberia]. Kemerovo, KSU, pp. 69-87.

Balonov F.R., 1996. Kult konya i kolesnitsy v skifo-sarmatskuyu epokhu u narodov evraziiskikh stepey i predgoriy: dis. ... kand. ist. nauk v forme doklada [The Horse and Chariot Cult in the Scythian-Sarmatian Era in the Population of Eurasian Steppes and Foothills. Cand. hist. sci. diss. in the form of a sci. report]. Saint Petersburg, SPbSU. 29 p. 
Griaznov M.P., 1955. Kolesnitsa rannikh kochevnikov Altaya [Chariot of the Early Altay Nomads]. Soobshheniya Gosudarstvennogo Ermitazha [Reports of the State Hermitage Museum], vol. VII, pp. 30-32.

Guk D.Yu., Nikolaev N.N., 2012. Povozka iz Pyatogo Pazyrykskogo kurgana [A Chariot from the Fifth Pazyryk Kurgan]. Kutury Stepnoy Evrazii i ikh vzaimodeistvie s drevnimi tsivilizatsiiami [Cultures of Steppe Eurasia and their Interaction with Ancient Civilizations]. Vol 2. Saint-Petersburg, IHMK RAS, Periferiya Publ., pp. 454-457.

Detlova E.V., Kuzminykh S.V., Malov N.M., 2019. P.S. Rykov i P.D. Rau v zerkale perepiski s uchenymi Zapadnoi Evropy (A.M. Tal'gren, G. Mergart, E.Kh. Minnz, T. Arne) [P.S. Rykov and P.D. Rau as Reflected in Correspondence with West European Scientists (A.M. Tallgren, G. Merhart, E.H. Minns, T.J. Arne)]. Arkheologiia VostochnoEvropeiskoi stepi [Archeology of the East European steppe], vol. 15. Saratov, SSU, pp. 224-298.

Klepikov V.M., 2017. Pogrebeniya rannesarmatskoy kul tury Nizhnego Povolzh ya s detalyami povozki v zaklade mogilnoy kamery [The Funeral Ceremony of Early Sarmatian Culture With the Items of the Carriage in the Top of the Burial Chamber (the Lower Volga Region)]. Vestnik Volgogradskogo gosudarstvennogo universiteta. Seriia 4. Istorija. Regionovedenie. Mezhdunarodnye otnoshenija [Science Journal of Volgograd State University. History. Area Studies. International Relations], vol. 22, no. 3, pp. 20-35. DOI: https://doi.org/ 10.15688/jvolsu4.2017.3.2

Kozhin P.M., 1969. O sarmatskikh povozkakh [On the Sarmatian vehicles]. Drevnosti Vostochnoy Evropy. K semidesyatiletiyu Alekseya Petrovicha Smirnova [Antiquities of Eastern Europe. Festschrift for Aleksey Petrovich Smirnov on the occasion of his $70^{\text {th }}$ birthday]. Materialy i issledovaniia po arkheologii SSSR, no. 169. Moscow, Nauka Publ., pp. 92-95.

Komarov A. M., Kuzmina O. V., Ivanov A. Iu., 1990. Otchet oraskopkakh kurgannykh mogilnikov u s. Politotdelskoe (Nikolaevskiy rayon), Khokhlachevskiy (Sredneakhtubinskiy rayon), u khutora Molokanovskiy(Oktyabrskiy raion), Kazachiy (Kotelnikovskiy rayon) i odinochnogo kurgana u s. Peskovatka (Kalachevskiy rayon) v zonakh stroitelstva orositelnykh sistem v Volgogradskoy oblasti v 1989 g. [Report on the Excavation of Kurgans near the village of Politotdelskoye (Nikolaevsky District), Khokhlachevsky (Sredneahtubinskiy District), nearby the farmstead of Molokanovsky (Oktyabrsky District), Kazachiy (Kotelnikovsky District) and a Single Kurgan near the village of Peskovatka (Kalachevsky District) in the Areas of Irrigation Systems Construction in the Volgograd region in 1989. Volgograd]. Arkhiv VOKM, no. 102.

Mamontov V.I., 1994. Kurgannyy mogilnik Antonov I [Kurgan Cemetery Antonov I]. Drevnosti Volgo-Donskikh stepey [Antiquities of the Volga-Don steppes]. Iss. 4. Volgograd, Peremena Publ., pp. 15-46.

Miniaev S.S., Sakharovskaya L.M., 2007. Khanskaya kolesnitsa iz mogilnika Tsaram [Han Chariot from the Tsaram Kurgan Cemetery]. Arkheologicheskie vesti [Archaeological News], iss. 14, pp. 130-140.

Rau P.D., 1929. Otchety o raskopkakh 1928 i 1929 gg. s dnevnikom, chertezhami, risunkami i fotografiyami [Reports on Excavations of 1928 and 1929 with Diary, Drawings, Pictures, and Photographs]. Archive of the Institute for the History of Material Culture of Russian Academy of Sciences. F. 2, Op. 1, no. 149.

Sinitsyn I.V., 1947. Arheologicheskie raskopki na territorii Nizhnego Povolzhya [Archaeological Excavations in the Lower Volga Region]. Saratov, SSU. 134 p.

Smirnov K.F., 1959. Kurgany u sel Ilovatka i Politotdelskoe Stalingradskoi oblasti [Kurgans near Ilovatka and Politotdelskoe Villages of the Stalingrad District]. Drevnosti Nizhnego Povolzhia [Antiquities of the Lower Volga Region]. Materialy i issledovaniya po arkheologii SSSR, no. 60. Moscow, AS USSR, pp. 206-322.

Smirnov K.F., 1960. Bykovskie kurgany [Bykov Kurgans]. Pamiatniki Nizhnego Povolzhia [Monuments of the Lower Volga Region]. Materialy i issledovaniya po arkheologii SSSR, no. 78. Moscow, AS USSR, pp. 169-268.

Stepanov P.D., 1925. Izdeliya iz dereva v kurganakh Suslovskogo mogilnika [Wooden Crafts in the Kurgans of Suslovsky Kurgan Cemetery]. In: Rykov P.S. Suslovskiy kurgannyy mogilnik [Suslovsky Kurgan Cemetery]. Uchenye zapiski Saratovskogo gosudarstvennogo universiteta [The Records of Saratov State University]. Vol. IV, iss. 3, pp. 76-81.

Fedorov-Davydov G.A., Dvornichenko V.V., Malinovskaya N.V., 1975. Otchet o raskopkakh kurganov v urochishhe «Krivaia Luka» v Chernoiarskom raione Astrakhanskoi oblasti v 1974 g. Moscow, 1975 [Report on Excavations of Kurgans in the Place of Krivaya Luka of the Chernoyarsk District of the Astrakhan Region in 1974. Moscow, 1975]. Vol. 1, 2, 3. Arkhiv Astrakhanskogo Museia-Zapovednika.

Liu Yonghua, 2002. Zhongguo Gu Dai Che Yu Ma Ju. Shanghai Shi, Shanghai ci shu chu ban she. 200 p.

Wagner M., 2004. Wagenbestattungen im bronzezeitlichen China. In: Fansa M., (Hrsg.) Rad und Wagen: Der Ursprung einer Innovation; Wagen im Vorderen Orient und Europa. Oldenburg-Mainz-Isensee, P. von Zabern. S. 107-122. 
Б.А. Раев. Повозки в сарматских погребениях нижневолжских и нижнедонских курганов

\section{Information About the Author}

Boris A. Raev, Candidate of Sciences (History), Senior Researcher, Federal Research Centre The Southern Scientific Centre of the Russian Academy of Sciences, Chekhov St., 41, 344006 Rostovon-Don, Russian Federation, boris_raev@mail.ru, https://orcid.org/0000-0001-6006-6173

\section{Информация об авторе}

Борис Аронович Раев, кандидат исторических наук, старший научный сотрудник, Федеральный исследовательский центр Южный научный центр Российской академии наук,

просп. Чехова, 41, 344006 г. Ростов-на-Дону, Российская Федерация, boris_raev@mail.ru, https://orcid.org/0000-0001-6006-6173 